\title{
UJI KUAT TEKAN DAN DAYA SERAP AIR PADA BATAKO DENGAN PENAMBAHAN LIMBAH TULANG IKAN
}

\author{
Sahara \\ Jurusan Fisika, Fakultas Sains dan Teknologi, Universitas Islam Negeri Alauddin Makassar \\ email: rarafis_uin@yahoo.co.id
}

\begin{abstract}
Batako or blocks of concrete is a material making up the walls of a house which is usually used as a substitute for bricks. The building blocks of concrete are cement and sand. In this study the block of concrete made with the addition of fish bone powder with a different composition. The purpose of this study was to determine how the effect of addition fish bone powder to compressive strength and water absorption in blocks. To obtain the results of the study, several stages of the research method were used, includes: making the sample of the brick test, the compressive strength test and water absorption. The test sample consisted of 7 samples with a mixture compositions B1 $=5 \%$ fish bone : $45 \%$ cement, B2 $=10 \%$ fish bone : $40 \%$ cement, B3 $=15 \%$ fish bone : $35 \%$ cement, B4 $=20 \%$ fish bone : $30 \%$ cement, B5 $=25 \%$ fish bone : $25 \%$ cement, B6 $=30 \%$ fish bone : $20 \%$ cement, $B 7=35 \%$ fish bone : $15 \%$ cement. The composition of water and sand is made constant with a mixture of $40 \%$ sand: $10 \%$ water. Then proceed with testing the compressive strength and water absorption of each sample. The results showed that the addition of $5 \%$ and $10 \%$ of fish bones into the aggregate of the concrete mix had an effect on increasing the compressive strength. Conversely, an increase above $25 \%$ results in a decrease in the compressive strength of the brick. When compared with SNI standards, samples B1, B2 and B4 could satisfy with Indonesian National standards (SNI) for concrete classes III and IV. For water absorption in all samples an average of $10 \%$ and also fits with the National standard (SNI) of water absorption whose value is a maximum of $25 \%$.
\end{abstract}

Keywords: fish bone, compressive strength, water absorption, blocks of concrete.

\section{PENDAHULUAN}

Seiring dengan pertambahan jumlah penduduk, kebutuhan akan perumahan semakin meningkat. Kondisi ini menyebabkan material penyusun rumah seperti dinding harganya juga semakin naik. Dalam hal ini, material yang dimaksud adalah batu bata. Lebih lanjut batu bata yang hanya dipoduksi pada musim kemarau sering juga hilang di pasaran. Kemungkinan disebabkan oleh bahan baku batu bata yaitu tanah yang juga semakin berkurang. Melihat kondisi ini, batako bisa menjadi alternatif pengganti batu bata yang mulai banyak diminati masyarakat karena bentuk dan ukurannya lebih besar dari batu bata yang memudahkan pengerjaan pemasangan dinding rumah.

Batako merupakan material yang berbentuk kotak menyerupai batu bata yang terbuat dari semen dan pasir serta tambahan air. Jika dibandingkan dengan batu bata, batako lebih rapuh dan kurang kuat untuk dijadikan penyusun material dinding. Hal ini yang memacu para peneliti terdahulu untuk mendapatkan kualitas 
batako yang lebih kuat dan kokoh. Adapun parameter yang digunakan untuk menentukan kekuatan batako adalah kuat tekan dan daya serap air.

Penelitian sebelumnya yang berkaitan dengan penambahan material lain untuk memperoleh kualitas batako yang lebih baik dapat ditemukan pada pada penelitian (Abdul Halim, 2013) tentang pengaruh pemakaian limbah styrofoam terhadap kuat tekan dan berat batako yang menunjukkan hasil bahwa batako semakin kuat jika styrofoam lebih kecil dari pasir. Pada penelitian lainnya seperti (Nuryanto H. d dkk.,2017) tentang Penambahan serbuk gergaji kayu Palapi ke dalam batako berpengaruh pada penyerapan air dan kuat tekan pada komposisi tertentu. Pada penelitian (Rizky D.A, dkk., 2014) juga tentang pengujian Kuat Tekan Batako Dengan Penambahan Semen Merah Dari Limbah Gerabah. (Henok Siagian, 2011) juga melakukan pengujian sifat mekanik batako yang dicampur abu terbang dimana hasil penelitiannya, pada campuran bahan batako sebanyak $5 \%$, $10 \%$, dan $15 \%$ dari berat semen menghasilkan kekuatan tekan rata-rata sebesar 20.76 MPa, 26.00 MPa dan 22.40 MPa. Lebih lanjut peneliti lainnya seperti (Hartanto, 2014) melakukan pengujian kuat tekan batako dari pecahan tempurung kelapa, dari penelitian tersebut telah disimpulkan pengujian kuat tekan batako kuat tekan maksimum terjadi pada penambahan pecahan tempurung kelapa sebesar $1 \%$ dengan menghasilkan nilai kuat tekan batako rata-rata sebesar 7.168 MPa.

Menurut Trilaksani, dkk (2006) tulang ikan merupakan salah satu bentuk limbah dari industri pengolahan ikan yang memiliki kandungan kalsium terbanyak diantara bagian tubuh ikan, karena unsur utama dari tulang ikan adalah kalsium, fosfor dan karbonat. Dalam penelitian ini penambahan tulang ikan yang dihaluskan ke dalam campuran batako merupakan ide baru dimana berdasarkan ketersediaan limbah tulang ikan yang banyak dijumpai di pelalangan ikan di Makassar dan kabupaten Takalar, rumah makan seafood dan kawasan industri perikanan. Selain itu dengan mengasumsikan bahwa kandungan tulang ikan yang terdiri dari kalsium dapat berfungsi sebagai perekat dan pengikat pada campuran semen dan pasir. Terdapat kesamaan komposisi antara semen, Pasir dan tulang ikan yaitu mengandung kalsium. Pada semen kandungan kalsium carbonat (batu kapur) merupakan penyusun terbesar selain silika dan alminium. Lebih lanjut pada pasir, khususnya pasir laut kandungan penyusun utamanya juga kalsium yang merupakan hasil dari serpihan cangkang kerang dan binatang laut lainnya.

Dari uraian diatas maka akan dilakukan penelitian untuk mengetahui kuat tekan dan daya serap air dengan memanfaatkan limbah tulang ikan sebagai campuran dalam pembuatan batako pada komposisi yang berbeda. Dengan penambahan limbah tulang ikan ini, diharapkan bisa memberi nilai tambah dengan diperolehnya suatu material batako yang lebih kuat dalam menerima tekanan dan daya serap air yang rendah serta kualitas yang lebih baik dibandingkan dengan batako yang sering dijumpai di pasaran. Lebih lanjut Pemanfaatan limbah tulang ikan ini akan memberi nilai lebih terhadap perbaikan ekonomi masyarakat dan pada akhirnya batako yang dihasilkan juga ramah terhadap lingkungan yang menjadi solusi dari permasalahan limbah tulang ikan.

\section{METODE PENELITIAN}

\section{Pengolahan Tulang Ikan menjadi Tepung}

Tulang ikan dicuci hingga bersih kemudian direbus dengan suhu $80^{\circ} \mathrm{C}$ selama 45 menit. Membersihan tulang yang telah direbus kemudian dicuci dengan air bersih untuk menghilangkan daging-daging ikan yang masih menempel pada tulang sampai cukup bersih. Tulang ikan direndam dalam larutan aseton selama 3 
hari. Tulang ikan dikeringkan menggunakan oven pengering selama 48 jam pada suhu $65^{\circ} \mathrm{C}$ dan kemudian dihaluskan menggunakan blender dan diayak menggunakan ayakan tepung.

\section{Pencampuran Bahan dan Pembuatan Batako}

Menyediakan bahan campuran batako yaitu semen PC, pasir, tepung limbah tulang ikan dan air. Mencampurkan semua bahan campuran batako yang telah ditakar hingga campurannya homogen dengan komposisi pada Tabel 1. Menuangkan adonan ke dalam cetakan yang berukuran Panjang $30 \mathrm{~cm}$, lebar 10 $\mathrm{cm}$ dan tinggi $15 \mathrm{~cm}$. Meratakan permukaan cetakan. Cetakan yang telah diisi campuran batako disimpan dalam ruangan perawatan selama 24 jam sampai batako menjadi kering. Membuat sampel uji sebanyak 7 buah untuk masing komposisi campuran seperti pada Tabel 1 di atas. Melakukan perawatan batako selama 21 hari.

Tabel 1. Persentase perbandingan campuran bahan

\begin{tabular}{|c|c|c|c|c|}
\hline \multirow{2}{*}{ Sampel Uji } & \multicolumn{4}{|c|}{ Komposisi perbandingan campuran } \\
& bahan & \multicolumn{4}{|c|}{$\begin{array}{c}\text { Tulang } \\
\text { ikan (\%) }\end{array}$} & $\begin{array}{c}\text { Semen } \\
(\%)\end{array}$ & $\begin{array}{c}\text { Pasir } \\
(\%)\end{array}$ & $\begin{array}{c}\text { Air } \\
(\%)\end{array}$ \\
\hline B1 & 5 & 45 & 40 & 10 \\
\hline B2 & 10 & 40 & 40 & 10 \\
\hline B3 & 15 & 35 & 40 & 10 \\
\hline B4 & 20 & 30 & 40 & 10 \\
\hline B5 & 25 & 25 & 40 & 10 \\
\hline B6 & 30 & 20 & 40 & 10 \\
\hline B7 & 35 & 15 & 40 & 10 \\
\hline
\end{tabular}

\section{Pengujian Kuat Tekan dari Batako}

Menyiapkan sampel benda uji batako. Mengukur dimensi panjang, lebar dan tinggi untuk masing-masing sampel yang akan diuji kuat tekannya. Meletakkan benda uji batakodengan kode sampel B1 pada alat uji kuat tekan. Mengatur jarum alat kuat tekan Forney tepat pada posisi nol. Menyalakan alat kuat tekan forney kemudian membaca jarum penunjuk beban, sambil memberikan beban tekan (F) dari atas perlahan demi perlahan sampai batako tersebut patah atau hancur. Pencatatan dilakukan saat jarum penunjuk skala tidak lagi bergerak atau bertambah. Mencatat besarnya nilai beban tekan maksimum yang terbaca pada jarum alat Forney. Mencatat data ke dalam tabel pengukuran. Mengulang kegiatan 4 sampai 8 dengan menggunakan bahan batako pada kode sampel komposisi yang sama. Mengulang kegiatan 4 sampai 9 dengan menggunakan bahan batako pada kode sampel komposisi yang berbeda.

\section{Pengujian Daya Serap Air}

Menimbang sampel uji untuk masing-masing komposisi untuk menentukan berat massa kering. Merendam sampel uji selama 24 jam, kemudian menimbang kembali untuk menetukan berat massa basah.

\section{HASIL DAN PEMBAHASAN}


Pada penelitian ini terdiri dari tiga tahap, yaitu tahap pembuatan batako, pengujian kuat tekan dan pengujian daya serap air. Pada tahap pembuatan batako, semua bahan-bahan dicampur dengan variasi kadar tepung tulang ikan dan kandungan Semen. Adapun bahan-bahan untuk membuat batako seperti Semen, pasir, air serta serbuk tulang ikan. Sampel uji terdiri dari 7 sampel dengan komposisi campuran B1 $=5 \%$ Tulang lkan: $45 \%$ Semen, B2 $=10 \%$ Tulang Ikan : $40 \%$ Semen, B3 = 15\% Tulang Ikan : $35 \%$ Semen, B4 = 20\% Tulang Ikan : 30 $\%$ Semen, B5 $=25 \%$ Tulang lkan : $25 \%$ Semen, B6 = 30\% Tulang Ikan: $20 \%$ Semen, B7 $=35 \%$ Tulang Ikan : $15 \%$ Semen. Komposisi air dan pasir dibuat konstan dengan campuran Pasir $40 \%$ : Air $10 \%$.

Ukuran batako yang dibuat berbentuk persegi panjang dengan ukuran Panjang $30 \mathrm{~cm}$, lebar $10 \mathrm{~cm}$ dan tinggi $15 \mathrm{~cm}$. Jumlah sampel uji yang dibuat sebanyak 21 buah dan dibiarkan mengering selama 21 hari. Pembuatan batako atau sampel uji ini dilakukan di Makassar.

Pada tahap pengujian, sampel yang telah dibuat dikirim ke laboratorium Balai Besar Industri dan Hasil Perkebunan kota Makassar untuk diuji kuat tekannya. Alat yang digunakan adalah alat uji kuat tekan merek Forney. Dengan penambahan beban tertentu yang di atas sampel uji dan kemudian terukur pada alat sebagai kekuatan bahan untuk menahan beban yang arti fisisnya disebut Kuat tekan. Hasil pengujian dengan variasi komposisi tulang ikan dan semen kuat tekan batako terangkum dalam tabel 2 .

Tabel 2. Hasil pengujian kuat tekan batako dari berbagai komposisi tulang ikan ke dalam campuran agregat batako.

\begin{tabular}{ccc}
\hline Kode Sampel & $\begin{array}{c}\text { Komposisi } \\
\text { Tulang Ikan (\%) }\end{array}$ & $\begin{array}{c}\text { Kuat Tekan } \\
\left(\mathbf{K g} / \mathbf{c m}^{\wedge} \mathbf{2}\right)\end{array}$ \\
\hline B1 & 5 & 33.42 \\
B2 & 10 & 45.82 \\
B3 & 15 & 12.55 \\
B4 & 20 & 23.19 \\
B5 & 25 & 8.48 \\
B6 & 30 & 7.81 \\
B7 & 35 & 9.59 \\
\hline
\end{tabular}

Pada penelitian ini dibahas secara detail pengaruh penambahan serbuk tulang ikan dalam pembuatan batako. Dengan komposisi serbuk tulang dan semen yang bervariasi. Dengan asumsi awal bahwa serbuk tulang ikan mempunyai kandungan yang mirip dengan semen. Signifikansi dari penelitian ini yaitu dengan penambahan serbuk tulang ikan ini akan bisa menggantikan atau mengurangi kadar semen dengan kuat tekan yang sesuai standar SNI.

Kualitas batako juga dapat terlihat dari kemampuan batako menyerap air. Pada tahap pengujian daya serap air pada umur 21 hari, terlihat hasil pada Tabel 3. Hasil pengujian diperoleh dengan menggunakan persamaan daya serap air (2). 
Tabel 3. Tabel hasil pengujian daya serap air untuk komposisi sampel tulang ikan yang berbeda.

\begin{tabular}{ccc}
\hline Kode Sampel & $\begin{array}{c}\text { Komposisi } \\
\text { Tulang Ikan (\%) }\end{array}$ & Daya Serap Air (\%) \\
\hline \hline B1 & 5 & 8.51 \\
B2 & 10 & 7.09 \\
B3 & 15 & 13.28 \\
B4 & 20 & 10.29 \\
B5 & 25 & 8.21 \\
B6 & 30 & 11.28 \\
B7 & 35 & 11.72 \\
\hline
\end{tabular}

Pada pembahasan ini akan didiskusikan tentang pengaruh penambahan serbuk tulang ikan terhadap kekuatan batako yang biasa disebut dengan kuat tekan. Di sini akan dilihat perkomposisi dengan sampel sebanyak 7 sampel yang diberi kode B1, B2...sampai sampel B7. Pada sampel B1, dengan komposisi $5 \%$ tulang ikan diperoleh kuat tekan $33.42 \mathrm{~kg} / \mathrm{cm} 2$. Pada sampel B2, komposisi $10 \%$ tulang ikan nilai kuat tekannya adalah $45.82 \mathrm{~kg} / \mathrm{cm} 2$. Untuk sampel B3 dan B4 dengan penambahan $15 \%$ dan $20 \%$ diperoleh masing-masing nilai kuat tekan sebesar 12.55 dan $23.19 \mathrm{~kg} / \mathrm{cm} 2$. Dan terakhir untuk sampel B5, B6 sampai B7 dengan penambahan $5 \%$ tiap komposisi dihasilkan nilai kuat tekan yang hampir konstan dengan rata-rata sebesar $8.62 \mathrm{~kg} / \mathrm{cm} 2$.

Pada grafik 1 terlihat bahwa kuat tekan pada sampel B1 dan B2 mengalami kenaikan dengan nilai kuat tekan sebesar $33.42 \mathrm{~kg} / \mathrm{cm} 2$ dan $45.82 \mathrm{~kg} / \mathrm{cm} 2$. Acuan yang digunakan adalah batako tanpa penambahan tulang ikan. Pada sampel B3 kuat tekan mengalami penurunan dan kemudian naik lagi kuat tekannya menjadi $23.19 \mathrm{~kg} / \mathrm{cm} 2$ pada sampel B4. Pada grafik juga terlihat trend yang mengalami penurunan untuk sampel B5 sampai B7. Peningkatan dan penurunan ini dapat dikaji dan dibahas dengan memperhatikan komposisi sampel yang berbeda. Lebih lanjut pembahasan ini lebih menarik dengan melihat secara detail komposisi tulang ikan dan semen.

Pada sampel B1 dan B2 nilai kuat tekannya masih besar kemungkinan disebabkan oleh komposisi semen dan tulang ikan sebagai pengikat batako pada campuran sangat dominan. Penelitian Syaifuddin 2018, dengan menggunakan alat X-Ray Diffraction (XRD, kandungan tulang ikan berupa batu kapur $(\mathrm{CaO}) 65$ $\%$, Seng Oksida (ZnO) $11 \%$, Fe2O3 22\% serta Cu4O 2\%. Hal ini menunjukkan bahwa komposisi tulang ikan mempunyai kesamaan dengan penyusun semen yaitu batu kapur. 


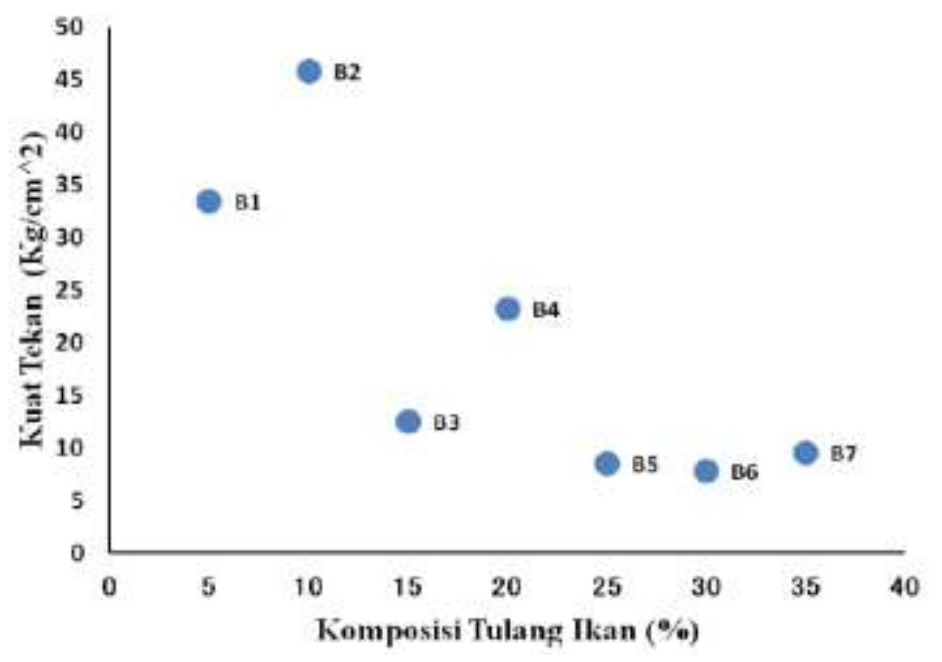

Gambar 1. Grafik hubungan Komposisi tulang ikan bervariasi dengan kuat tekan pada pembuatan batako

Lebih lanjut, Kandungan semen juga mempunyai kadar $\mathrm{CaO}$ sebesar 60 $65 \%$ (Tjokrodimulyo 1996). Disini terlihat bahwa kandungan semen dan kandungan serbuk tulang ikan mempunyai komposisi yang sama. Dengan penambahan $5 \%$ dan $10 \%$ tulang ikan dapat mempengaruhi kenaikan kuat tekan batako. Dimana diperoleh nilai kuat tekan batako maksimum pada penambahan $10 \%$ atau terlihat pada sampel B2.

Pada Sampel B3 terlihat penurunan jika dibandingkan dengan sampel B2 dan B4 Hal ini kemungkinan oleh campuran bahan-bahan yang tidak homogen (Tidak rata ikatannya tiap partikel). Pendapat ini didukung oleh nilai daya serap air terbesar ada pada sampel B3 yaitu sebesar $13.28 \%$. Nilai kuat tekan yang mengalami penurunan kemungkinan juga disebabkan oleh posisi jarum alat ukur yang belum stabil setelah pengukuran sebelumnya.

Pada sampel B5, B6 dan B7 nilai kuat tekannya mengalami penurunan dibanding sampel B4 dapat dianalisis dari komposisi tulang ikan yang sudah tidak proporsional pada campuran. Sampel tersebut sudah rapuh dan gampang pecah. Pada komposisi ini tulang ikat yang dominan tidak dapat mengikat bahan-bahan agregat seperti pasir, semen dan air secara utuh. Kekuatan batako ini berkurang karena adanya komposisi lain pada kandungan serbuk tulang ikan seperti seng oksida, Besi dan Tembaga (Syaifuddin 2018).

Jika dibandingkan dengan standar Nasional Indonesia (SNI) kuat tekan beton, sampel B1, B2 dan B4 memenuhi kuat tekan Bruto rata-rata minimal yang termasuk dalam kategori kelas III ( $35 \mathrm{~kg} / \mathrm{cm} 2)$ untuk sampel B2 dan kelas IV (20 $\mathrm{kg} / \mathrm{cm} 2$ ) untuk sampel B1 dan B4. Disini penambahan kuat tekan maksimum kategori kelas III terlihat pada B2 dengan penambahan tulang $10 \%$. 


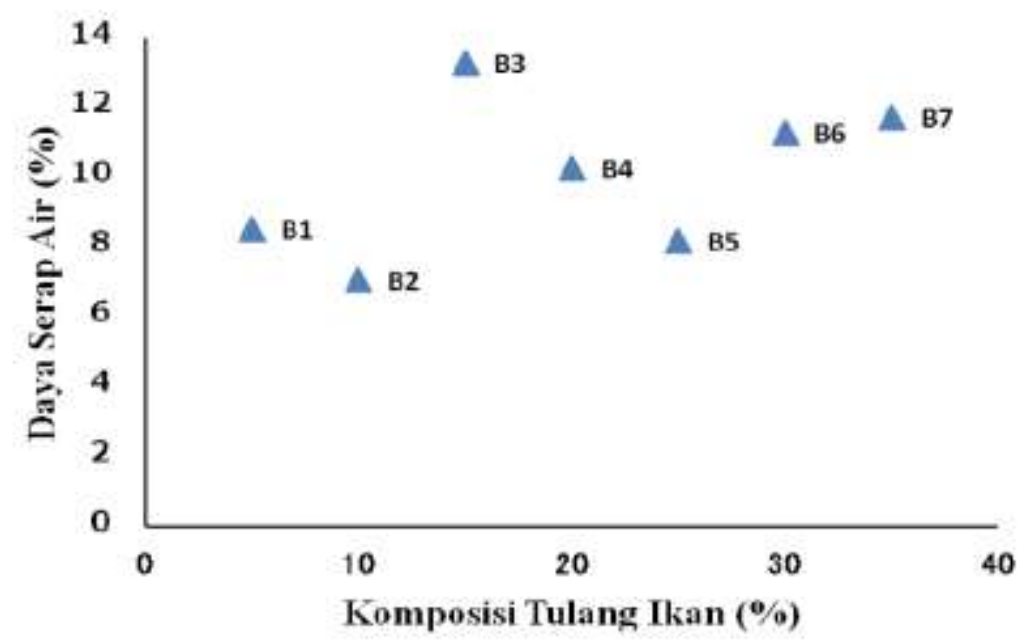

Gambar 2. Grafik hubungan komposisi tulang ikan dengan daya serap air pada agregat campuran batako.

Daya serap air merupakan parameter uji sifat fisis dari batako. Pengujian ini bertujuan untuk melihat banyak pori-pori yang ada pada batako. Semakin besar daya serap airnya maka batako tersebut semakin rapuh. Untuk batako sendiri ada standar maksimal SNI sebesar $25 \%$ untuk beton kelas I. Pada grafik 1.2 terlihat hubungan daya serap air dengan komposisi sampel tulang ikan. Dari keseluhan sampel diperoleh daya serap air rata-rata sebesar $10 \%$.

\section{SIMPULAN}

Berdasarkan penelitian yang telah dilakukan dapat disimpulkan bahwa penambahan $5 \%$ dan $10 \%$ tulang ikan ke dalam agregat campuran batako berpengaruh pada peningkatan nilai kuat tekan. Sebaliknya penambahan diatas $25 \%$ mengakibatkan penurunan nilai kuat tekan batako. Sampel B1, B2 dan B4 memenuhi standar Nasional Indonesia (SNI) beton kelas III dan IV. Daya Serap air untuk semua sampel rata-rata $10 \%$ dan memenuhi standar Nasional (SNI) penyerapan air yang nilainya maksimal $25 \%$.

\section{DAFTAR PUSTAKA}

Abdul Halim, 2013. Pengaruh Pemakaian Limbah Styrofoam terhadap kuat Tekan dan Berat Batako., Widya Teknika Vol. 21. No.1. Hal. 1-7.

Hartanto, Kukuh. 2014. Pemanfaatan Limbah Pecahan Tempurung Kelapa Sebagai Bahan Tambah Pada Campuran Bahan Baku Batako.Tugas Akhir. Universitas Muhammadiyah Surakarta.

Nuryanto Hafid Wahyudi, Erniwati, dan Abdul Hapid, 2017. Karakteristik Batako dan Campuran semen dan Sebuk Gergajian Kayu Palapi, Warta Rimba, Vol. 5. No.1, Hal. 100-106.

Rizky Dian Anggakusuma, Supardi, dan Edy Purwanto, 2014. Kuat Tekan Batako Dengan Penambahan Semen Merah Dari Limbah Gerabah, e-Jurnal Matriks Teknik Sipil, Hal. 328-335.

Syaifuddin, 2018 Pembuatan dan Pengujian Kuat Tekan Batako dengan Penambahan Tulang Ikan. Undergraduate (S1) thesis, Universitas Islam Negeri Alauddin Makassar. 
Siagian,Henok, Dkk. 2011. Pengujian Sifat Mekanik Batako Yang Dicampur Abu Terbang (Fly Ash). Jurusan Fisika, FMIPA, Universitas Negeri Medan.

Trilaksani, dkk, 2006. Pemanfaatan Limbah Tulang Ikan Tuna (Thunnus Sp.) Sebagai Sumber Kalsium Dengan Metode Hidrolisis Protein, Buletin Teknologi Hasil Perikanan, Vol IX No. 2. 